\title{
БРЯНСКИЙ КРАЙ МЕЖДУ ГОСУДАРСТВОМ РОССИЙСКИМ И РЕЧЬЮ ПОСПОЛИТОЙ: ПОЛИТИКА, РЕЛИГИЯ, ЯЗЫК (XVI-XVIII ВВ.)
}

\section{ЕЛЕНА КОШКИНА}

\author{
Национальный исследовательский университет „Высшая школа экономики” \\ Департамент иностранных языков \\ ул. Мясницкая, 20, 101000 Москва, Россия \\ e-mail: e-lena-koshkina@yandex.ru \\ ORCID: https://orcid.org/0000-0002-4463-9071
}

\section{ЮЛИЯ РОМАНЧЕНКО}

\author{
Национальный исследовательский университет „Высшая школа экономики” \\ Департамент иностранных языков \\ ул. Мясницкая, 20, 101000 Москва, Россия \\ e-mail: juliaroman@yandex.ru \\ ORCID: https://orcid.org/0000-0002-1914-6013 \\ (получено 2.08.2018; принято 11.09.2018)
}

\section{Abstract \\ Bryansk Territory between the State of Russia and the Polish-Lithuanian Commonwealth (Rzeczpospolita): politics, religion, language}

The purpose of this paper is to present the history of the Bryansk Territory as one of the border regions of Russia in the context of the contradictory relationship between the Russian and Polish-Lithuanian states (XVI-XVIII centuries) and the conflict of religious and social systems. Moreover, the geographically and historically conditioned linguistic heterogeneity of this region is pointed out. The author examines the influ- 
ence of extralinguistic factors (political, religious, cultural processes and contacts with foreign countries) on the development of language in the border region.

\section{Key words}

Moscow State, Rzeczpospolita, Time of Troubles, Bogdan Khmelnitsky, Bryansk dialects and their features, Baltic, Polish, Belarusian, Ukrainian borrowings in the Bryansk dialects.

\section{Резюме}

Цель статьи - представить историю Брянского края как одного из пограничных регионов России в контексте противоречивых взаимоотношений Российского и Польско-Литовского государств, конфликта религиозных и социальных систем, а также описать географически и исторически обусловленную языковую гетерогенность этого края, рассмотреть влияние экстралингвистических факторов (политических, религиозных, культурных процессов и контактов с зарубежными странами) на развитие языка в пограничном регионе.

\section{Ключевые слова}

Московское княжество, Речь Посполитая, Смута, Богдан Хмельницкий, брянские говоры и их особенности, балтийские, польские, белорусские, украинские заимствования в брянских говорах.

Как известно, приграничные территории всегда имеют сложную, порой драматичную историю, переходя из рук в руки и стойко переживая все тяготы неоднозначных политических решений центрального руководства. Брянский край не стал исключением в этом ряду. Находясь на юго-западном рубеже Государства Российского, он прошел через многие испытания в своей тысячелетней истории.

Следует отметить, что на карте современной России Брянская область появилась лишь после Второй мировой войны, когда она была образована Указом Президиума Верховного Совета СССР 5 июля 1944 года из городов и районов Орловской области, располагавшихся приблизительно в границах существовавшей ранее Брянской губернии. В состав области вошли города областного подчинения Брянск, Бежица и Клинцы (Ведомости Верховного Совета СССР, 1944, № 36).

На карте можно увидеть ее актуальное административное деление и границы с соседними регионами России (Смоленская Калужская, Орловская, Курская области), Украины (Сумская, Черниговская) и Белоруссии (Гомельская, Могилевская). 


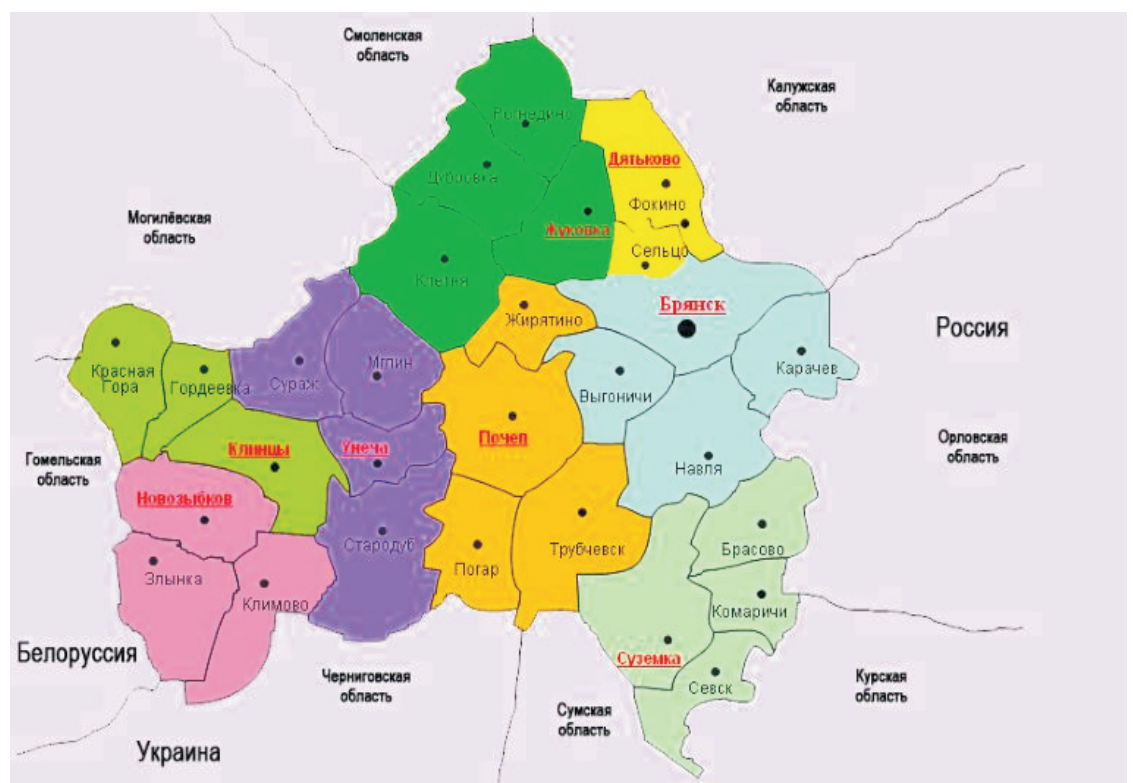

Карта 1. Административное деление Брянской области и границы с соседними регионами Источик: Карта Брянской области. [Online:] http://ruhov-school.ucoz.ru/Futag/karta_brjanskoj_oblasti_1. jpg (18.07.2018).

Согласно историческим хроникам, более 600 лет назад, точнее в XIV-XV вв., эти земли также находились в центре военных тяжб между Московским и Литовским княжествами, которые на тот момент уже имели вес на политической арене Европы и ожесточенно воевали. В 1356 г. русское княжество с центром в городе Дебрянск (Брянеск, Брянск) вошло в состав Великого княжества Литовского и было упразднено им в 1401 году. Лишь спустя столетие, в 1500 г., московские войска вернули брянские территории; в 1503 г. под руководство московского князя перешли добровольно Стародубское и Новгород-Северское княжества, земли князей Мосальских и Трубецких (Крашенинников, 2001, ч. 1).

Возникший в XVI веке европейский политический союз „Речь Посполи́тая (польск. Rzeczpospolita) - федерация Королевства Польского и Великого Княжества Литовского как результат Люблинской унии в 1569 г." (Большая российская энциклопедия, 2004-2017) - дал новый виток историческим переменам на приграничных территориях. В отличие от молодого и мощного соседнего государства Россия того периода находилась в упадке и хаосе, после того как пресеклась правящая династия Рюриковичей и шла ожесточенная многолетняя борьба за власть между различными группировками.

Эпоха Смуты (1598 - 1613 гг.) вошла в историю как годы стихийных бедствий, экономического и государственного кризиса, интервенции инородцев (походы Лжедмитрия I и II при поддержке польских властей, в частности польского короля Сигизмунда III). В результате хаоса страна утратила значительную часть своей территории и понесла существенные потери в численности населения. 
Длительные противоречия Смутного периода окончились Деулинским перемирием между воюющими государствами, заключенным в с. Деулино близ Троице-Сергиева монастыря 1 декабря 1618 г. сроком на 14 лет. Стремясь быстрее выйти из войны, Россия вынуждена была отдать Польше 29 городов: Смоленск вместе с Дорогобужем и Рославлем, Чернигов и Новгород-Северский, из брянских земель - Стародуб, Попову (ныне Красную) Гору, Почеп, Трубчевск и др. Поляки требовали еще и Брянск, но русские послы тогда не уступили: сам Брянск, а также Карачев с уездами и Севск с Комарицкой волостью остались за Россией (Говоров, Соколов, 1955, с. 56). Хотя позднее Польско-Литовскому государству в разные периоды принадлежали как сам Брянск, так и Погар, Мглин, Сураж, Севск и десятки других, более мелких населенных пунктов. Таким образом, до 90 процентов брянской территории (особенно на западе и юге) переходили в подчинение новой власти.

В пределах внутренних границ Речи Посполитой Великое княжество Литовское создало из полученных русских земель Смоленское воеводство, которое делилось на два повета ${ }^{1}$ (округа): Смоленский и Стародубский. В состав Смоленского повета вошли 8 русских уездов. В Стародубский повет, кроме одноименного уезда, вошли также следующие уезды: Почепский, Трубчевский, Поповогорский. Последний уезд был неполноценным: с 1618 г. Попова Гора находился во владении Могилевского Спасского кафедрального собора (Бабушкин, 1958, с. 20-23).

В начале 1620 г. королевские комиссары провели ревизию вновь приобретенных Польшей замков и распределили земельные наделы между переехавшими в эти края польскими шляхтичами. Поляки начали активно заселять доставшуюся им область, привлекая сюда переселенцев с помощью разного рода льгот. Такая политика имела успех, и за время польского владычества возникло около 300 новых поселений. Земли в окрестностях Стародуба, например, получили поляки Николай Абрамович (который владел также Мглином и округой), Александр Пясочинский, Ян Куницкий, Кшиштоф Фаш и другие (Брянску - 1000 лет..., 1986, с. 15). Они стали укреплять города, предполагая использовать их в качестве крепостей при потенциальных конфликтах с Москвой. Такой крепостью и стал Стародуб, который именовали замком; а крестьян, нанятых для защиты города, - замковой прислугой. В 1620 г. она насчитывала не более двух десятков человек. Несколькими годами позже ее количество возросло уже до сотни.

Также в Стародубском повете было образовано четыре хоругви (роты), которые выступали как основные военно-тактические единицы, нанимались во время войны на определенный срок с определенной численностью и жалованием для служащих (казаков), набор которых осуществлялся ротмистром. В период военных действий казакам выплачивалось жалованье, а остальное время

1 „Пове́m (по́вят от польск. powiat ['povjat], укр. повim, белор. павет) - административнотерриториальная единица в Великом княжестве Литовском и Речи Посполитой, а также нынешняя средняя административно-территориальная единица в Республике" (Этимологический словарь русского языка, 1987, т. 3, с. 293). 
они „служили с земли”. Каждый казак, служивший на своем коне, получал „на каждый конь” участок усадебной земли и 4 волоки полевой земли (одна волока равнялась 21,36 га). Казакам предоставлялось право владеть крестьянами, они были освобождены от платежа податей и несения других повинностей. Стародубская хоругвь насчитывала 100 всадников, Почепская - 50, Мглинская - 100, Трубчевская - 30. Позднее вместо Трубчевской была создана Погарская, поскольку к середине XVII в. Речь Посполитая и Москва были вынуждены заключить военный союз против татар, а Трубчевск по договору 1644 г. был возвращен Московскому государству (Мастерская „Зброевы фальварак”, 2015).

Хоругвью также именовался и стяг воинского казацкого формирования, который являлся одновременно и территориальным знаменем: на нем изображались территориальные эмблемы земель, входивших в состав княжества. Например, Стародубской казацкой сотне по привилею² 1626 г. дозволялось „иметь хорогву особую красную с крестом голубым, которая должна быть в дозоре” (Соколов, 2001, с. 78). Известна еще одна хоругвь более позднего времени, периода казацких войн 1649-1654 гг. Во главе Стародубской хоругви стоял польский шляхтич Ян Славинский. На зеленом полотнище были изображены Архангел Михаил (герб Смоленского воеводства), крест, подобный тому, что изображен на других хоругвях, и родовой герб (Богория) самого шляхтича с буквами по сторонам: I - Ян, S - Славинский, M - мечник, S - Стародубский (Деханов, 2013, c. 124).

Большей части городов Стародубского повета польским королем Сигизмундом III было пожаловано магдебургское право: Стародубу - 15 февраля 1620 г., Мглину - 26 марта 1626 г., затем - Погару³. Есть сведения о том, что таких же привилегий в первой половине XVII в. удостоился и Почеп. Это делалось для скорейшего развития и укрепления рубежей „крымской Украины”, т.е. земель, служивших щитом от крымских татар. Предоставление привилегий (льготный режим налогообложения, изменение правил наследования, вдвое сниженный размер судебных штрафов и проч.) способствовало скорейшему восстановлению городов, опустошенных войной, а с другой стороны, как бы уравнивало их в правах с иными городами Речи Посполитой и содействовало воспитанию лояльности к новой власти у населения захваченных территорий.

2 „Привиле́й (от лат. privilegium - специальный закон; польск. przywilej) - законодательный акт в Королевстве Польском (с XII века) и Великом княжестве Литовском (с конца XIV века), представляющий собой жалованную грамоту, дававшуюся монархом отдельным лицам, сословиям, этно-конфессиональным группам или землям" (Советская историческая энциклопедия, 1973-1982).

3 Магдебу́ргское пра́во (нем. Magdeburger Recht) - „одна из наиболее известных систем городского права, сложившаяся в XIII веке в Магдебурге как феодальное городское право, согласно которому экономическая деятельность, имущественные права, общественно-политическая жизнь и сословное состояние горожан регулировались собственной системой юридических норм, что соответствовало роли городов как центров производства и денежно-товарного обмена. В Польше магдебургское право получило распространение в XIII-XIV вв. и фиксировалось путем выдачи грамот - привилеев. Право магдебурское” (Энииклопедический словарь Брокгауза и Ефрона, 1890-1907). 
Суть нового самоуправления сводилась к тому, что горожане не обязаны были подчиняться никакому другому суду, кроме избираемого из их же среды суда магистрата. Если представитель негородского сословия приобретал себе в городе дом и землю, он также обязался подчиняться магистрату. Работой магистрата и жизнью в городе руководил войт (староста), избираемый горожанами. В магистрате также хранились городская казна, архив и печать. На стародубской печати был изображен святой Георгий Победоносец. Вместе с магдебургским правом жаловались и гербы. Предоставление городского герба - это показатель государственной политики в вопросе самоуправления покоренных городов. На пожалованном Стародубу польским королем гербе был изображен дуб с орлиным гнездом (Деханов, 2013, с. 125) .

От польского короля те же стародубцы получили ряд важных привилегий, за которые держались вплоть до XIX века: в Стародубе в день святого Юрия Римского позволялась ярмарка; всем горожанам разрешалось заниматься винокурением и торговать вином за небольшую налоговую пошлину. Горожане также были обязаны молоть свой хлеб на городской мельнице и содержать эту мельницу в порядке. Кроме того, горожане должны были за свои деньги вооружаться и в случае нападения оборонять городскую крепость. Все эти порядки были установлены и со временем приняты местным населением.

Однако, было несколько аспектов, с чем не могли смириться стародубцы: поляки хотели обратить их в католичество. Идейным руководителем этого процесса стал польский король Сигизмунд III, который был воспитан иезуитами и оставался всю жизнь приверженцем католической унии. Главной своей задачей он видел упрочение в Речи Посполитой католицизма, уничтожение как протестантизма, так и православия. Уже в 1625 г. здесь предписывалось избирать в магистрат только католиков или униатов (христиан, сохранивших православную церковную службу, но подчиненных главе католиков Папе Римскому). Войта перестали избирать - его назначали польские власти также из числа поляков и католиков. Потом делопроизводство в магистрате перевели с русского языка на польский, а позже, спустя 20 лет, собирались перевести с польского на латинский.

Позднее поляки начали проводить новую церковную политику даже с помощью силы. Так, в 1631 г. в Стародуб прибыл представитель католического смоленского епископа и потребовал от местного православного духовенства признать верховенство Римского Папы. Получив отказ, католический эмиссар закрыл стародубские церкви, опечатал их двери. Все это было описано в исторических хрониках так: „... русские церкви поломали. А которые... стародубцы жилецкие люди не похотели быть под их ляцкаю вераю, и тех... стародубцав бискуп смоленский велел, переимав, бить и приводить их в лядецкую веру неволею. И от тово... стародубцы многие разбежались розно”. Католический епископ Леонтий Кривза еще более жестко принялся насаждать новую веру среди православных: людей били до тех пор, пока те не примут католичество, разрушали православные храмы, закрыли православный Спасский монастырь и открыли католический францисканский (Воссоединение Украины с Россией. Документь и материаль, 1953, т. 1, с. 588). 
Удивительно, но при этом многие русские дворяне сохранили за собой поместья, например, стародубские дети бояр Рубцы и Бороздна. За „сыновьями боярскими” Яковом, Дмитрием, Осипом и Владимиром Борозднами польское правительство утвердило „дедичные” их вотчины: с. Медведеве, дер. Куршиновичи, разные „селища” по рекам Снови, Трубеже, Титве, Росухе и др. Акт поясняет, что все эти имения Бороздны получили от великих князей русских, как засвидетельствовали „боярове тамошние”, показавшие, что всеми перечисленными имениями владели и предки братьев. Их огромные поместья, занимавшие значительную часть теперешних Новозыбковского, Климовского, Стародубского, Мглинского районов, говорят о том, что Бороздны были едва ли не главными землевладельцами уже в 16 столетии. У Осипа Бороздны в 1638 году было усадебное место с постройками в Стародубе на Могилевской улице (Поклонский, 1998 , с. 56).

Приняв, по необходимости, польский язык, используемый при дворе и на сейме, они скоро переменили и веру, потому что эта перемена открывала им дорогу к получению от польского короля прав и всеобщему одобрению шляхетского сословия. Дети дворян учились за границей: в Австрии, во Франции, в Испании, Италии, а также во внутренних городах Речи Посполитой (Кракове, Львове), где иезуиты полностью контролировали процесс воспитания и вели его в рамках догматов римско-католической церкви. Ярким примером такого семейства стал князь Юрий Никитич Трубецкой, законный наследник Трубчевска. Половину Трубчевского уезда получил он в 1621 г. от польского короля боярин, перейдя для этого в католичество. Юрий Никитич и его сын Петр верой и правдой служили польским королям, боролись с казацкими восстаниями, преследовали православие в своих землях. Тогда же трубчевский Свято-Троицкий собор, где находится родовая усыпальница Трубецких, приобрел черты католического храма-костела. Позднее, когда Трубчевск вернулся в подданство русского царя, внук Юрия Никитича, князь Юрий Петрович Трубецкой, перешел в православие и уехал в Москву.

Вторая половина Трубчевска и уезда принадлежала непосредственно польскому королю, здесь селились переехавшие из Речи Посполитой шляхтичи и горожане. Один из таких шляхтичей, П. Салтык, выстроил в Трубчевске, неподалеку от Троицкого собора, католический храм (1640-1645 гг.), который после возвращения города России 1644 г. был переделан в православную церковь во имя Преображения Господня, но сохранил в народе название „костел” (Наш Карачев - Информационный портал города и области, 2010).

Простой народ со временем начал проявлять недовольство и выступать против религиозного притеснения и польского владычества, следствием которого стало разорение и упадок крестьянских хозяйств. Сельские наделы сократились, уменьшилось количество скота, и крестьянам приходилось пользоваться панским скотом за дополнительные повинности. Увеличилось число малоземельных и безземельных крестьян, вынужденных наниматься в батраки на крайне тяжелых для них условиях. Безграничная власть панов подтверждалась многими сеймовыми постановлениями. Шляхта продавала или дарила своих крестьян, распоряжалась их наследством, имела над ними неограничен- 
ную судебную власть. Паны обладали так называемым правом меча, т.е. правом жизни и смерти по отношению к своим подчиненным. Против панского гнета крестьяне защищались всеми средствами. Они бежали от своих панов, отказывались выполнять повинности, убивали.

Со временем во главе борьбы стародубцев за свою независимость от католической Польши, за сохранение православной веры и единение с Москвой стал гетман Богдан Хмельницкий, под руководством которого малороссийское и стародубское казачество начало свое освободительное движение. Судьба городов Брянского края решалась в польско-казацких и русско-польских войнах. Летом 1648 г. казаки Хмельницкого освободили от поляков Погар, Стародуб, Почеп; в конце лета 1648 г. одним из центров антипольского восстания стала Попова (Красная) Гора, куда прибыли казацкие отряды атаманов Горкуш, Кривошапки, Микулицкого и др. (Костомаров, 1993)

Долгие войны истощили обе воюющие стороны, поэтому Россия и Речь Посполитая решили пойти на переговоры. Они начались еще в 1664 г., а закончились только в 1667 г. В селе Андрусово около Смоленска было подписано перемирие. Россия возвратила себе Смоленск, приобрела Северские земли и всю Левобережную Украину. Русско-польский договор завершил большую полосу в жизни юго-западных уездов России. Местные крепости потеряли свое прежнее военное значение. Край перестал быть пограничным, так как юго-западный рубеж России отодвинулся до Днепра и за Смоленск. Жизнь местного населения потеряла свой боевой характер. Сложились условия для роста населения, дальнейшего хозяйственного освоения края, укрепления благосостояния крестьян и горожан, подъема торговли, развития культуры.

С тех времен в Стародубе сохранился полковой казачий собор во имя Рождества Христова, выстроенный в 1677 г., где молились полковники и гетманы, а также читались царские указы и гетманские универсалы, хранили свои полковые и взятые в бою вражеские знамена, здесь приносили присяги и отпевали павших казаков. Влияние малороссов в те годы было значительным и в церковной области.

Таким образом, Брянщина, особенно та ее часть, что расположена на правой стороне реки Десны, за три столетия оказывалась под постоянным влиянием своих сильных соседей, а ее жители „образовали переходную народность между великороссиянами и малороссиянами” - как считал известный украинский историк Н. Костомаров (1993, с. 54) - вобрав в себя черты этих культур, мировоззрений и языков.

В связи с этим особого внимания заслуживает анализ языковой ситуации, сложившейся на территории Брянской области в настоящий момент и являющейся результатом выше описанных исторических, социальных и культурных событий.

Исследователи-языковеды отмечают, что в силу своего географического положения - граничит с Украиной на юге и с Белоруссией на западе - территория Брянщины в этнографическом и лингвистическом отношении уникальна, поскольку здесь сходятся три восточнославянских этноса. Соответственно, 
характер брянских говоров ${ }^{4}$, по мнению О.А. Антиповой, складывался на протяжении веков в условиях тесного контактирования трех восточнославянских языков - русского, украинского и белорусского.

Более того, на территории Брянщины постоянно и в течение долгого времени осуществлялись экономические, культурные и языковые контакты не только русского, украинского, белорусского населения, но и других, в первую очередь, литовского и польского. Поэтому именно этот регион на протяжении многих лет привлекает внимание как историков, краеведов, этнографов, так и лингвистов (Абакумова, 2014, т. 4, с. 53).

Обратимся далее к истории исследования Брянских говоров. Первые записи местной речи на Брянщине были сделаны в 1850 г. уроженкой с. Рассуха М. Н. Косич. Ее книга была удостоена золотой медали Русского Географического общества. Также сохранились две рукописи А. Столохова, этнографа середины XIX в., давшего описание и местный словарь Трубчевского, Брянского и Карачевского уездов (1850-е годы). Известен также обширный труд уроженца г. Брянска П. Н. Тиханова Брянский говор, заметки из области русской этнологии (с приложением словаря).

С 1903 г. П.А. Расторгуев собирает материал для Словаря народных говоров Западной Брянщины, который выходит в 1973 г. и включает 8 тыс. слов. Источниками послужили словарные материалы, собранные лично автором, студентами Новозыбковского пединститута, а также извлечения из печатных записей А.Д. Нечаева, А.Н. Афанасьева, А.Ф. Полевого, М.В. Ушакова (Словарь народных говоров Западной Брянщины..., 1973, с. 14-15).

С целью экспедиционного обследования говоров и последующей работы над региональным словарем территория Брянской области была закреплена за Санкт-Петербургским педагогическим университетом им. А. И. Герцена. Возглавила работу профессор В. И. Чагишева. Под ее руководством на кафедре русского языка составлена и продолжает составляться Картотека Брянского словаря. В 1968 г. вышел 1 выпуск Словаря брянских говоров (под ред. В.И. Чагишевой). Сейчас таких выпусков уже пять. Из наиболее известных исследователей 50-80-х годов XX века можно отметить работы ученых В.Н. Новопокровской, Г.И. Демидовой, А.В. Королькова, Л.М. Чистяковой и А.М. Родионовой-Нащекиной, которые являются последователями и учениками В.И. Чагишевой. В 80-90-е годы продолжают заниматься исследованием брянских говоров (напр., Батожок, 1994; Абакумова, 2014; Седойкина, 2011).

4 Говор, как одна из форм существования языка, наряду с литературным языком и диалектом, определяется как „наименьшая территориальная разновидность языка, которая используется в качестве средства общения жителями одного или нескольких соседних, обычно сельских, населенных пунктов, не имеющих территориально выраженных языковых различий. Говор отличается от систем других говоров своеобразием фонетических, грамматических, словообразовательных и лексических черт" (см. Лингвистический энииклопедический словарь, 1990).

5 Многие теоретические вопросы в сравнительном изучении близкородственных говоров остаются практически неразработанными. Об актуальности проблем, связанных с семантической реконструкцией и анализом диахронических изменений в значениях слов, а также 
Среди исследователей, занимающихся Брянскими говорами, нет единого мнения относительно их принадлежности. Так, в течение XIX-XX вв. изучаемые говоры рассматривались по-разному: как белорусские (Карский, Расторгуев); как южновеликорусские (Будде, Чагишева); как переходные от белорусских к южновеликорусским с белорусской основой (Голанов). В частности, Расторгуевым, уроженцем Брянской области, говоры Брянщины были классифицированы как южновеликорусские. Соглашаясь, однако, с тем, что эти говоры имеют белорусскую основу, Расторгуев ${ }^{6}$ предлагал выделять их в отдельную группу „северско-белорусскую” (Абакумова, 2014, с. 54).

Как особую группу южновеликорусского наречия, обладающую известным единством, но при этом не представляющую единообразия, рассматривает Брянские говоры Чагишева (Седойкина, 2011).

На Диалектологической карте русского языка брянские говоры отнесены к Верхне-Деснинской группе южного наречия, которой свойственны черты языковых комплексов западной, юго-западной и южной диалектных зон, выделяемых преимущественно на основе их фонетических и грамматических особенностей (Кузнецов, 1973, с. 276).

В настоящее время говоры центральной части Брянской области называют южнорусскими (смоленскими) говорами западной группы. Они сформировались на территории, где в XIII-XVI вв. был распространен смоленско-полоцкий диалект древнерусского языка.

Учеными установлено, что основные диалектные черты говоров Западной группы складывались в феодальный период в условиях разобщенности русских земель в границах Смоленского княжества, позднее - Смоленской земли и Смоленского воеводства в составе Великого княжества Литовского.

Типичные южнорусские черты говоров можно проследить как на фонетическом, так и грамматическом и, конечно же, лексическом уровне.

\section{Фонетические особенности}

Насчитывается 63 особенности.

1. Появление 2, напр., гастра (ср. лит. астра, Батожок, 1994).

2. Диссимиляция ${ }^{7}$ двух согласных дентального ряда, напр., в брянском гремучий (лит. дремучиц̆), колидор (лит. коридор), коклета (лит. котлета), тран-

проблемы, связанные с построением генетической классификации близкородственных языков и диалектов и необходимости их разработки писали К.Ф. Захарова, В.Г. Орлова, Ф.П. Филин, Н.П. Гринкова, Н.И. Толстой, О.Н. Трубачев, А.С. Герд, Д.С. Азарх, С.В. Бромлей, Ф.П. Сороколетов, И.А. Попов, З.А. Козырев, В.М. Мокиенко, А.Ф. Журавлев, Л.А. Ивашко, О.С. Мжельская, О.Е. Кармакова, Р.М. Козлова, О.Д. Кузнецова, Н.Н. Пшеничнова и др.

6 „...постепенно говоры современной Западной Брянщины: утрачивают черты своей старой основы и приобретают южновеликорусский характер. Исходя из этого, говоры современной Западной Брянщины следует называть южновеликорусскими (развивавшимися в прошлом и развивающимися теперь в настоящем на белорусской основе)" (Расторгуев, цит. по: Абакумова, 2014).

7 Диссимиляция - „процесс обратный ассимиляции, то есть два или более одинаковых или близких по типу звука расходятся в произношении все дальше. Диссимиляция выражается 


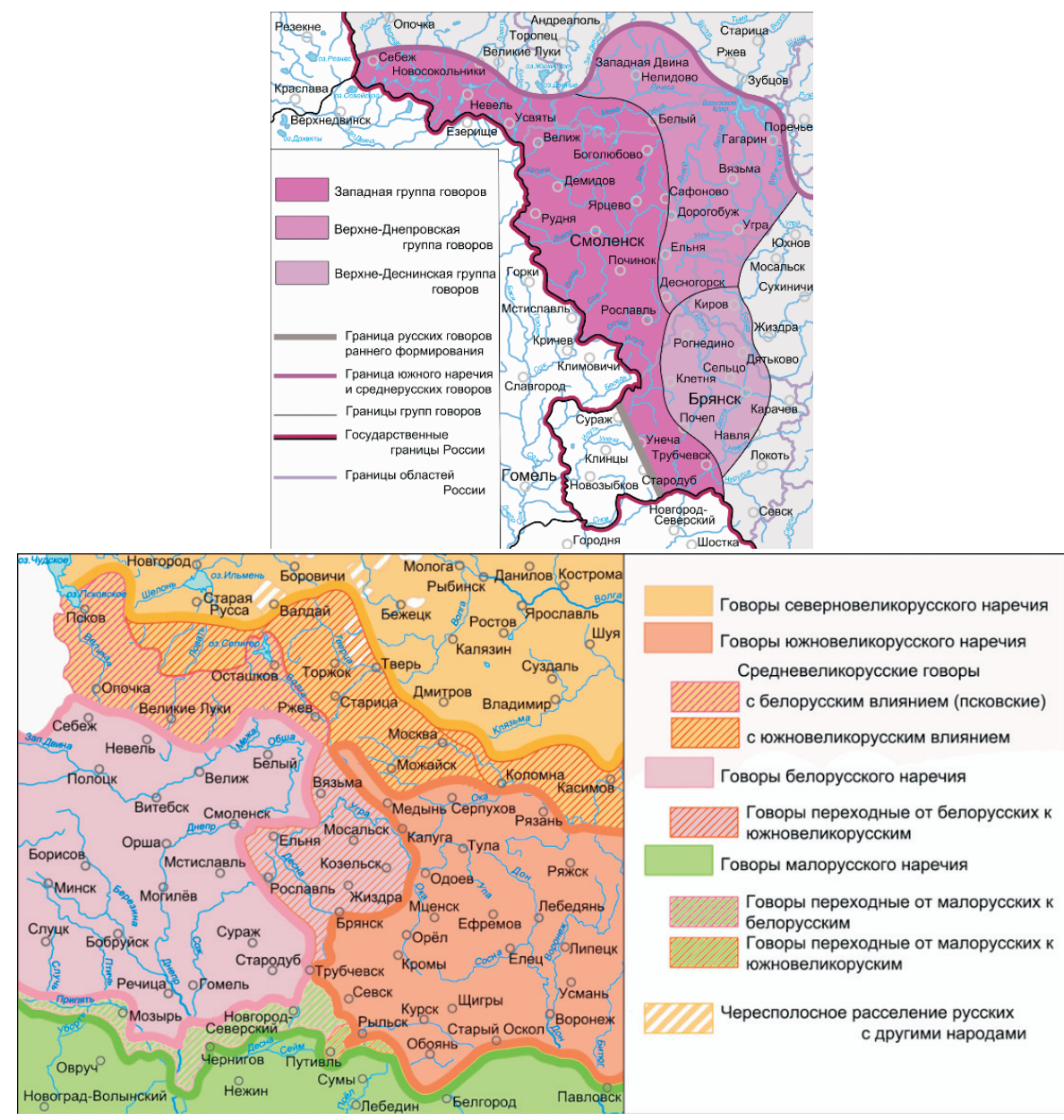

Карта 2. Западные южнорусские говоры

Источник: https://yandex.ru/images/search?text=говоры\%20брянской\%20области\&img_url (11.09.2018).

вай (лит. трамвай), ндравиться (лит. нравиться), феврарь (февраль) (Батожок, 1994).

3. Аканье (неразличение гласных неверхнего подъема после твердых согласных): карова, табе, сабе, м[б]локо́ (молоко), м[ъ]лова́m (маловат), аборка (оборка 'тонкая веревка').

4. Яканье (замена $е$ на $я$ ) (присутствует в говорах современного белорусского), напр.: звязда (звязда), бягу (бегу), нясу (несу), особенно в Стародубском районе Брянской области ${ }^{8}$.

в замене одного из двух одинаковых или похожих (по месту образования) звуков другим, менее сходным по артикуляции с тем, который остался без изменений” (Лингвистический энииклопедический словарь, 1990).

8 Стародубье - исторически сложившаяся территория на юго-западе Брянской области, расположенная на стыке России, Украины и Белоруссии. Соответственно, население Стародубщины состояло из представителей трех народов - украинцев, белорусов и русских. 


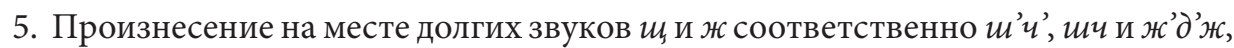
ждж, напр., ищчу, дож'д’жик, вожджи (особенно это характерно для Унечского района ${ }^{9}$ Брянской области).

6. Наличие звонкой задненебной фонемы фрикативного типа /Y/ и ее чере-

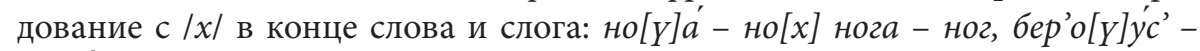
бер'о' $[x]$ с'а берегусь - берегся.

7. Появление интервокального $ј$ в иноязычных словах, напр., no[jə]m, unu[jo] $\mathcal{H}$ (особенно это характерно для Унечского района Брянской области).

8. Отсутствие ассимиляции по назальности бм $\rightarrow$ мм: о[бм]а́н, о[бм]е́р’ал.

9. Появление вместо в неслогового $y$, напр.: аутобус (автобус), аутор (автор), (особенно это характерно для Стародубского района Брянской области).

10. Прилагательные имеют ударение на первом слоге, как в белорусском и украинском языках: седьмой ([c'o]

11. Вариативность в произношении местоимения 3-го лица мн. ч., именно появление $е$ и я вместо $o, e$ в личных местоимениях, напр., они-яны, он-ен, онаяна (как в белорусском и украинском, особенно это характерно для Стародубского района Брянской области).

12. Наличие /j/ в основе в формах указательных местоимений: $m[a \dot{u} a]$ (ma) -

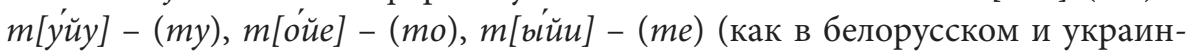
ском).

\section{Грамматические особенности}

1. Окончание -е в форме родительного падежа ед. ч. у существительных жен-

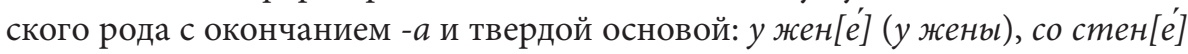
(со стень).

2. Совпадение безударных окончаний 3-го лица мн. ч. глаголов I и II спряже-

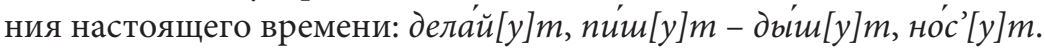

3. Наличие особых форм личного и возвратного местоимения с окончанием -e в родительном и дательном падежах и различение основ родительного сравнительно с дательным падежом: р. п. (y) мене, тебе, себе; д. п. (ко) мне, тобе, собе (особенно это характерно для Унечского района Брянской области).

4. Наличие безударного окончания -ы у существительного ср. рода с твердой основой в форме именительного падежа мн. ч., напр., окны (особенно это характерно для Унечского района Брянской области).

5. Совпадение безударных окончаний 3 лице мн. ч. глаголов I и II спряжений, напр., пишуть, делають, дыиуть, носють (особенно это характерно для Унечского района Брянской области).

\section{Словообразовательные особенности (Батожок, 1994)}

1. Образование существительных при помощи суффикса -ак: се̂д[áк] (седок), ход[áк] (ходок) (как в белорусском и украинском).

9 В состав Брянской области Унечский район вошел с июля 1944 г. 
2. Наличие приставок пры-, пря- вместо пре-, напр.: прямудры, прымудры, в глаголах прыбавить (особенно это характерно для Стародубского района Брянской области).

3. Замена суффикса -л в глаголах прошедшего времени на -в: пришев, сделав, сказав и т.д.

4. Корневое соответствие со словами литературного языка: галдишь (галдеть), голубеи (голубь), гордливыцй (гордый), горлач (кувиин), городавый (городской), глядины (смотринь) и др.

\section{Грамматические особенности}

Наличие конструкций с предлогом с или з в случаях типа прие́хал з го́рода, вылез с я́мы в соответствии с предлогом из и другие диалектные черты (как в белорусском и украинском языках).

\section{Лексические особенности}

Распространение слов: зе́лени, зеленя', зе́ль ('всходы ржи'); лю́лька ('подвешиваемая к потолку колыбель'); коре́и, корччик (в значении 'ковш'); дежа', де́жка ('посуда для приготовления теста'); гре́бовать (в значении 'брезговать').

\section{Стилистические особенности}

Если литературному языку свойственна четкая дифференциация: высокий - нейтральный - низкий (очи - глаза - гляделки и тому подобное), то в говорах слова высокого или низкого стиля могут выступать как нейтральные.

\section{Семантические особенности}

1. Расхождение значений диалектного и литературного слов, напр.: мост „пол”, орать - „пахать”, угадать - „узнать”, больно - „очень”, веснушка „лихорадка”, худой - „плохой”, страдать - „убирать урожай”, поманить - „подождать”, застать - „запереть”, парить - „высиживать изыплят”, погода - „дождb, снег” (особенно это характерно для Унечского района Брянской области).

2. Многозначность, вызванная происхождением слов „от различных лексем литературного языка или местных говоров в силу стремления народа к образному номинированию и реализации широко распространенного семантического способа словообразования" (Седойкина, 2010, с. 116-120), напр.: желтяк - 1. „человек с желтым цветом лица”, 2. „желтый огурец”;

гламазд - 1. „человек, несоразмерный в частях, нестройный, неуклюжий”, 2. „человек, не соблюдающий порядка, неопрятный”, 3. „слишком большой, занимающий много места; громоздкий";

mльпух - 1. „толстое полено или бревно”, 2. „то же, что тарбуль (колода для рубки дров)”, 3. перен. „о неуклюжем, неповоротливом человеке”;

жгалка - 1. „муха с колющими щетинками на хоботке, которая появляется осенью и больно кусается”, 2. перен. „противная, нерасторопная женщина”; 
кверзень - 1. „вид обуви, сплетенной из лык, чаще липовых”. 2. „лапти, сделанные грубо, кое-как, наспех” (пренебр.); 3. перен. „о человеке недобром, способном на каверзы” (Седойкина, 2010, с. 116-120).

3. Большое количество синонимических рядов, напр.:

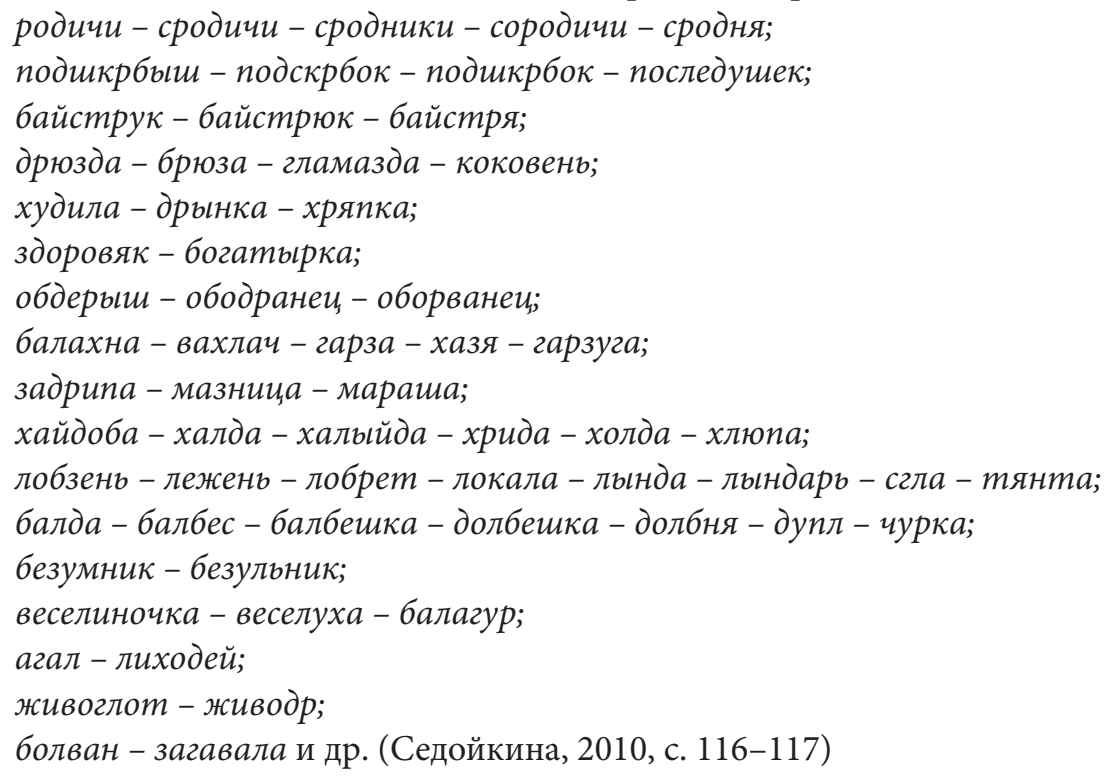

4. Особенности номинации - метонимия.

При номинации, особенно человека, в брянских говорах зачастую используется метонимия - перенос наименования с одного денотата на другой благодаря сходству:

- с животным миром и миром птиц (жигалка, жук, вужака, ведмедь, вылупок, глухарь, казоря / казарка - шумныци, крикливыци человек);

- по цвету (беляк, желтяк);

- с бытовым предметом (ветренка, кувалда);

- с одеждой или обувью (каверень);

- с деревянным предметом (дуnл, тельпух);

- с игрушкой (дзыга, брязготка);

- с музыкальным инструментом (дуда, бубен);

- с продуктами питания (хряпка, репа) и т.д. (Седойкина, 2010, с. 118).

5. Наличие устойчивых словосочетаний, в которых реализуются возможности разносторонней характеристики человека:

1) особенностей его характера, поведения:

- докучливая басня (о надоедливом, навязчивом человеке),

- комара не зашибет (о человеке, который никого не обидит),

- кила наговорная (болтливый человек).

2) внешних физических особенностей:

- казиные тиски (худой, малорослый человек любого возраста, но чаще всего ребенок),

- старый гриб (о человеке старом и слабом),

3) умственных способностей: 
- балда понеделишная (бестолковый человек),

- голова не стегает (о человеке, который не может что-то придумать, сообразить),

- не хватает одной клепчины (о глупом человеке),

- монуса кусок (о глупом человеке),

4) трудовой деятельности:

- от земли (о человеке, который любит трудиться на земле),

- жирки точить (о деятельном, энергичном человеке),

- бринды бить, байды бить,

- льнды бить (бездельничать, избегать работы),

- лодырь от комля (ленивый от рождения человек),

5) благосостояния человека:

- по нем беда не ходила (о человеке, который не испытывал нужду, не бедствовал),

6) другие, напр. на лыко ремня искать - “искать выгоды”, горькую редьку грьзть - “жить в тяжелых условиях", виски дыбором - “очень испугаться”) и т.д. (Седойкина, 2010, с. 116-120)

Седойкина считает, что в брянских говорах представлено немного слов и фразеологизмов, отражающих материальную сторону жизни брянцев в прошлом. О благоприятных условиях жизни свидетельствуют только два выражения: божья благодать „полный достаток” и по нем беда не ходила „о человеке, который не испытывал нужду, не бедствовал”. Немногим больше выражений с отрицательной коннотацией: выходить на ботвинью ('вступать в брак с неимущим'), кишка кишке кукиш кажет ('голодать'), грызть горькую редьку ('жить в тяжелых условиях'), как у бога за дверями ('плохо жить') (Седойкина, 2010, с. $116-120)$.

Далее хотелось бы остановиться на рассмотрении лексического состава брянских говоров. Описанию его особенностей посвящены статьи Абакумова (2014) и Пенюковой (2011), Батажок (1994) и др.

Анализируя лексику брянских говоров, остановимся, прежде всего, на проблеме заимствований. Н.И. Батажок (1994, с. 5) говорит, в частности, о многочисленных заимствованиях из балтийских языков (в частности, литовского) ${ }^{10}$. Для удобства представим примеры в табличной форме (см. табл. 1) (Кожинова, Щербач, 2005).

Что касается заимствований из польского языка, А.А. Кожинова и И.М. Щербач, ссылаясь на Виноградова отмечают, что с XV в. до 20 гг. XVII века именно польский язык выступает в качестве поставщика большого лексического пласта определенного рода слов и понятий, а именно: научных, юридических, административных, технических, светско-бытовых. Интересно в этой связи отметить, что они зачастую заимствуются польским из западно-европейских (см. Кожинова, Щербач, 2005).

10 Проблемой балто-славянского взаимодействия занимались также Ю.А. Лаучюте, М.И. Лекомцева, В. Откупщиков. 
Таблица 1. Заимствования из балтийских языков в брянских говорах

\begin{tabular}{|c|c|c|}
\hline в брянском говоре & в литовском языке & комментарий \\
\hline $\begin{array}{l}\text { ринджоль - вид } \\
\text { саней }\end{array}$ & $\begin{array}{l}\text { лит. grizulas - дышло, } \\
\text { поворотный плуг }\end{array}$ & $\begin{array}{l}\text { польск. диал. - низкие неокованные } \\
\text { сани для соломы } \\
\text { белорус. гринджолы - большие сани } \\
\text { для перевозки больших бревен } \\
\text { укр. кгринджолы - санки }\end{array}$ \\
\hline лупатыци - губастый & $\begin{array}{l}\text { лит. lupa- губа } \\
\text { лит. lapo/as - } \\
\text { губастый }\end{array}$ & $\begin{array}{l}\text { белорус. лупа - губа } \\
\text { лупаты - губастый / с толстыми } \\
\text { губами }\end{array}$ \\
\hline $\begin{array}{l}\text { гаплик - крючок для } \\
\text { застегивания }\end{array}$ & $\begin{array}{l}\text { лит. kabliukas - } \\
\text { крюк, крючок } \\
\text { для застегивания } \\
\text { одежды }\end{array}$ & \\
\hline $\begin{array}{l}\text { глумость, глумкой } \\
\text { - глуповатый, } \\
\text { придурковатый }\end{array}$ & $\begin{array}{l}\text { лит. glumus -дурак, } \\
\text { глупость, лит. glumiti } \\
\text { - дурачить, сбивать } \\
\text { с толку }\end{array}$ & \\
\hline $\begin{array}{l}\text { глоботь - отнимать, } \\
\text { присваивать чужое }\end{array}$ & лит. globti - отнимать & $\begin{array}{l}\text { польск. glabac - хватать, забирать } \\
\text { себе, отнимать }\end{array}$ \\
\hline $\begin{array}{l}\text { андарак- род } \\
\text { крестьянской } \\
\text { домотканой юбки }\end{array}$ & $\begin{array}{l}\text { лит. andarokas - } \\
\text { полосатая шерстяная } \\
\text { юбка }\end{array}$ & $\begin{array}{l}\text { ср. в смоленских говорах (из } \\
\text { белорус. яз.) - сарафан } \rightarrow \text { символ } \\
\text { женской неволи и замужества }\end{array}$ \\
\hline
\end{tabular}

Источик: собственная разработка.

В говоры русского языка такие заимствования приходят, в частности, через старо-белорусский язык, как это произошло, например, с глаголом дяковати (от польск. dziękować, ср. нем. danken). В южных говорах западной группы есть существительное с этим корнем - дяка (благодарность) и глагол дякать / дяковать (проявлять благодарность).

В польском языке широко используется лексема пан, обозначавшая изначально статус вышестоящего лица по отношению к слугам, подчиненным, крестьянам. В русских говорах ее семантика развивается в нескольких направлениях. Производными лексемами описывались понятия, обозначающие зажиточность, богатство, счастливую, разгульную жизнь. В южных говорах богатого человека называли панник, панниться значило жить, ничего не делая. По народным представлениям, возникло и обозначение причины зажиточной счастливой жизни - самостоятельность, независимость, работа: пановать - вести хозяйство, распоряжаться чем-либо.

Из польского языка, точнее, из одного его диалекта, заимствуется лексема ŝmulac - тереть один предмет о другой (корень ${ }^{\star} \hat{s} m u l-/{ }^{\star} \hat{s} m o n-/{ }^{*} \hat{s} m u n-/{ }^{\star} \hat{s} m a n-$ с общим значением движения, трения, приводящего к сглаживанию, исчезновению неровностей). Проникая в брянские говоры в форме обшмуляться, лексическая единица получает значение 'перетереться' (ср. укр. мулити - жать, 
давить, не давать покоя), а в форме обшмаргивать лексема означает 'обрывать листья' (Кожинова, Щербач, 2005).

От польск. łotr 'плут, злодей’ происходит брянское лотра 'развратница' и лоmрыга 'бездельник, плут; человек, который непрочь и взять что-н.' (Седойкина, 2011, с. 116-120).

Как и в большинстве случаев лексема попала в язык брянцев не напрямую, a, скорее, посредством белорусского и украинского языков, ср. бел. лотра 'лодырь, лентяй, бездельник', укр. лотр 'вор, разбойник, грабитель, бездельник, плут, негодяй'.

Относительно заимствований из белорусского и украинского языков ${ }^{11}$, можно с уверенностью утверждать, что таковых в брянских говорах больше всех остальных, особенно в пограничных районах, которым является упомянутый ранее Стародубский район (Седойкина, 2011; Тарасова, 2012).

Таблица 2. Заимствования из белорусского и украинского языков в брянских говорах

\begin{tabular}{|l|l|l|l|l|}
\hline литературное & брянское & украинское & белорусское & ближе к \\
\hline скамейка & услон & ослон & заслон & укр. \\
\hline бочонок & цеберь & цебер & бачонак, вядро & укр. \\
\hline крючок & чепок & чипок, & $\begin{array}{l}\text { кручок, } \\
\text { ланцужок }\end{array}$ & укр. \\
\hline качели & рели & орели & арэли & белорус. \\
\hline шелуха от семечек & шелупашки & лушпайки & шалупайки & белорус. \\
\hline ящик & скрынка & скрынька & белорус. \\
\hline форточка & фортка & хвиртка & фортка & белорус. \\
\hline картошка & бульба & картопля & бульба & белорус. \\
\hline беготня & бяганина & биганина & летанина & укр. \\
\hline клецки & галушки & галушки & клецки & укр. \\
\hline льдина & крыга & крижина & крыга & белорус. \\
\hline $\begin{array}{l}\text { молодой парень, } \\
\text { жених }\end{array}$ & молодиг & $\begin{array}{l}\text { молодик - } \\
\text { юноша, холостой } \\
\text { мужчина / } \\
\text { молодой месяц }\end{array}$ & молодой месяц & укр. \\
\hline $\begin{array}{l}\text { пустослов, } \\
\text { хвастун }\end{array}$ & бугбен & $\begin{array}{l}\text { бубен - ворчун и } \\
\text { бормотун }\end{array}$ & белорус. \\
\hline
\end{tabular}

Источик: собственная разработка.

11 Важно отметить, что определяя источник заимствований, следует исходить не из общности корня в соответствующих словах близкородственных языков, а из полного совпадения состава морфем и семантики сопоставляемых слов. Только такие образования могут быть надежным свидетельством действительного заимствования того или иного брянского слова из близкородственных языков. (Тарасова, online). 
Е.С. Абакумова, исследуя заимствования из белорусского и украинского языков, полагает, что их большая часть является литературными в том и другом языке (Абакумова, 2014, с. 54-55).

К диалектным номинациям, являющимся литературными в белорусском языке, относятся, напр. анучка, апиуги, вильчик, вышки, дежка, куфайка, манарка, махотка, пеколок, саян, услон.

Литературными в украинском языке являются такие лексемы брянских говоров, как апценьки, бриль, дровник, дерюга, батырка, чоботь, иибка.

К литературным и в белорусском, и в украинском языке относят такие лексические единицы (ЛЕ), как, напр.: бахилы, бидон, вышки, горище, глек, жниво, запина, запон, заслонка, камора, кареи, клямка, комен, кузик, куток, кулеш, начевки, обутка, олей, печурка, пуня, склянка, сподница, тын, хата, хвортка, хустка, иеберь, чирики (Абакумова, 2014, с. 54-55).

Кроме того, все ЛЕ можно распределить, по мнению Е.С. Абакумовой, еще на четыре группы (см. табл. 3).

Таблица 3. Группы белорусских и украинских заимствований в брянских говорах (фонетический и семантический аспект)

\begin{tabular}{|c|c|c|c|}
\hline Группа 1 & Группа 2 & Группа 3 & Группа 4 \\
\hline $\begin{array}{l}\text { украинские } \\
\text { и белорусские ле } \\
\text { с фонетической } \\
\text { и лексической } \\
\text { эквивалентностью }\end{array}$ & $\begin{array}{l}\text { вариативное написание, но } \\
\text { одинаковое лексическое значение }\end{array}$ & \begin{tabular}{|l} 
одинаковое \\
произношение \\
и написание, \\
но разное \\
лексическое \\
значение
\end{tabular} & \begin{tabular}{|l|} 
вариативное \\
написание \\
и разное \\
лексическое \\
значение
\end{tabular} \\
\hline $\begin{array}{l}\text { бидон, глек, жниво, } \\
\text { махотка, клямка, } \\
\text { ухват, хата, хустка. }\end{array}$ & $\begin{array}{l}\text { анучка (белорус. ануча), } \\
\text { апиеньки (укр. обиеньки), } \\
\text { бахильь (укр. бахили), } \\
\text { вильчик (белорус. вільчак), } \\
\text { вышки (белорус. вышкі), } \\
\text { горище (белорус. горышча), } \\
\text { дежка (белорус. дежа), заслонка } \\
\text { (укр. заслон), кареи (белорус. карэи, } \\
\text { укр. кореи), } \\
\text { комен (белорус. комін, укр. комин), } \\
\text { кузик (белорус. гузік, укр. гудзик), } \\
\text { кулеш (укр. кулиш), } \\
\text { куток (укр. кут), } \\
\text { обутка (белорус. абутак, укр. } \\
\text { обуття), } \\
\text { олей (белорус. алей, укр. олія), } \\
\text { пеколок (белорус. пяколак), } \\
\text { сподница (белорус. спадніца, укр. } \\
\text { спідниця), тын (укр. тин), } \\
\text { батырка (укр. кватирка), }\end{array}$ & $\begin{array}{l}\text { склянка } \\
\text { диал. и белорус. } \\
\text { банка, сосуд с } \\
\text { горлышком } \\
\text { укр. - стакан; } \\
\text { саян } \\
\text { диал. и. } \\
\text { сарафан } \\
\text { белорус. - } \\
\text { шерстяная } \\
\text { домотканая } \\
\text { юбка }\end{array}$ & \begin{tabular}{|l} 
диалектное \\
запон - \\
фартук, \\
украинское \\
запона - \\
застежка на \\
манжетах \\
у рубашки; \\
диалектное \\
апцуги - \\
плоскогубцы \\
для \\
выдирания \\
гвоздей, \\
белорусское \\
апцугі - \\
щипцы.
\end{tabular} \\
\hline
\end{tabular}




\begin{tabular}{|c|c|}
\hline & $\begin{array}{l}\text { хвортка (белорус. фортка, укр. } \\
\text { хвіртка), чебать (укр. чоботи), } \\
\text { чрики (белорус. чаравік, укр. } \\
\text { черевики). }\end{array}$ \\
\hline $\begin{array}{l}\text { фонетическая } \\
\text { и лексическая } \\
\text { эквивалентность } \\
\text { диалектных } \\
\text { и белорусских } \\
\text { номинаций }\end{array}$ & $\begin{array}{l}\text { фонетическая и лексическая } \\
\text { эквивалентность } \\
\text { диалектных и украинских } \\
\text { номинаций }\end{array}$ \\
\hline 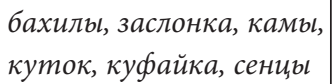 & бриль, горище, шибка. \\
\hline
\end{tabular}

Источик: собственная разработка.

Абакумовой делается вывод о том, что большая часть диалектных слов брянских говоров является литературной нормой в белорусском и украинском языках. Но может встречаться вариативность в произношении, написании и лексическом значении (Абакумова, 2014, с. 58-59).

Интересные наблюдения над лексическими единицами брянских говоров проводит И.В. Пенюкова, выбрав в качестве материала исследования медицинскую лексику (Пенюкова, 2011). На примере этого лексического пласта в говорах Брянщины и украинском языке автор пытается выявить общность языковых корней и культуры близкородственных народов. В процессе анализа исследователь констатирует случаи расхождения в значении, например, брян. вогник 'нарыв, болячка на лице, шее'. В украинском огник означает 'огонек'. Однако в брянском говоре, богатом на заговоры, существует народное „заклинание” от названного недуга 'Огник, огник, забери (имя) вогник'12.

Анализ медицинского пласта лексики в Брянских говорах и украинском языке еще раз подтверждает факт наличия многочисленных омонимов и „семантических разночтений" (см. табл. 4).

12 Выявляя мотивацию именования того или иного физического недуга, автор приходит к выводу, что большое значение имеют суеверие и языческие верования. Названия болезни табуировалось, люди старались избегать прямого наименования недуга. „В пользу древности данного процесса говорит наличие в обоих языках одинаковых словесных форм, сходных в своих значениях. В частности, для обозначения повышения температуры тела (лихорадки) в украинском языке употребляется слово лихоманка 'лихорадка', имеющее сходное звучание и значение в брянских говорах" (Пенюкова, 2011).

Вера в то, что любой физический недуг - это наказание за грехи, также нашло отражение в обозначениях болезней. Ср. рус. прострел ('острая боль в пояснице'), укр. пристріт ('болезнь от дурной встречи, сглаз'), а также существующее в Бряких говорах проклятье „Шоб тябя удар вдарив" (Пенюкова, 2011). 
Таблица 4. Омонимы и „семантические разночтения” в брянских говорах и украинском языке

\begin{tabular}{|c|c|c|c|c|}
\hline \multicolumn{2}{|l|}{ брянское } & \multicolumn{2}{|l|}{ украинское } & \multirow[t]{2}{*}{ комментарий } \\
\hline ЛЕ & значение & ЛЕ & значение & \\
\hline говоруха & лекарша & говоруха & $\begin{array}{l}\text { многоречивая } \\
\text { женщина }\end{array}$ & факт полисемии \\
\hline $\begin{array}{l}\text { гуля (ср. } \\
\text { польск. gula - } \\
\text { шишка) }\end{array}$ & отек, грыжа & $\begin{array}{l}\text { Гуля } \\
\text { (звукоподр.) }\end{array}$ & голубь & \\
\hline рожа & $\begin{array}{l}\text { кожное } \\
\text { заболевание } \\
\text { (ярко- } \\
\text { розовые очаги } \\
\text { воспаления) }\end{array}$ & ср. рожевий & розовый & \\
\hline проруха & $\begin{array}{l}\text { ошибка, } \\
\text { оплошность }\end{array}$ & $\begin{array}{l}\text { поруха } \\
\text { порух }\end{array}$ & $\begin{array}{l}\text { смещение органа } \\
\text { движение }\end{array}$ & \\
\hline пранцы & $\begin{array}{l}\text { неприятная } \\
\text { болезнь, } \\
\text { в переносном } \\
\text { значении } \\
\text { „кукиш” }\end{array}$ & & $\begin{array}{l}\text { венерическое } \\
\text { заболевание }\end{array}$ & $\begin{array}{l}\text { в качестве наговора } \\
\text { в брянском говоре } \\
\text { „што б тоби пранцы } \\
\text { сели”; в переносном } \\
\text { значении „пранцау } \\
\text { табе, а не меду” }\end{array}$ \\
\hline
\end{tabular}

Источик: собственная разработка.

Сопоставительное исследование лексики позволяет говорить о постоянных и длительных контактах между славянскими языками, их диалектной и литературной формой. Из анализа значения лексических единиц можно сделать вывод о воздействии на язык различных экстралингвистических факторов (суеверие, религия и т.д.), так и о ряде интралингвистических процессов: заимствования, утрата языковой системой лексической единицы, развитие полисемии, изменение семантической структуры (расширение, сужение, ухудшение значения), изменение сферы употребления и т.д (Пенюкова, 2011).

Тенденции развития диалектов и говоров зависит от ряда экстра- и интралингвистических факторов. В качестве важного неязыкового фактора, определяющего развитие современных говоров, можно назвать отношение к ним как со стороны носителей литературного языка, так и со стороны самих носителей говоров. Сравнивая свой „родной язык” с литературным, жители определенной местности оценивают свой говор как нечто „темное, старое, некрасивое”. Молодое поколение либо уже не владеет диалектной „нормой”, либо сознательно от нее отказывается. В результате многие слова переходят в пассивный слой лексики, вытесняются из памяти и, соответственно, постепенно выходят из употребления. 
В первую очередь утрачивается предметная лексика, описывающая реалии, которые уходят в прошлое, например посуда для приготовления в русской печи - махотка, чапяла; виды одежды - аппинка, поставка, саян.

Дольше сохраняется лексика, связанная с тематикой погоды, домашнего хозяйства: обрат (пропущенное через сепаратор, обезжиренное молоко), морянка (ветер с моря), сеногной (дождливая погода в конце лета), растворить тесто (поставить, замесить), лентяйка (швабра).

Самой „живучей” является экспрессивная лексика. Эмоциональная оценка остается всегда, независимо от процессов, происходящих в языке, а выразительные средства диалекта в этом отношении необычайно разнообразны (Антипова, 2016).

Подводя итог проделанной работы, обозначим полученные результаты. В первой части исследования была описана история Брянского края как одного из пограничных регионов России в контексте противоречивых взаимоотношений Российского и Польско-Литовского государств, был рассмотрен многовековой конфликт религиозных и социальных систем. Такая уникальная историческая, социальная и политическая ситуация нашла отражение в особенном языковом развитии Брянской области.

Вторая часть исследования была посвящена проблеме языковой гетерогенности, в частности брянскому говору, который, вобрав в себя характерные черты языка соседей, получил целый ряд особенностей на разных уровнях языка. Особое внимание было уделено лексическому уровню, а именно, многочисленным заимствованиям.

\section{Библиография}

Абакумова, Е. С. (2014). Тематическая группа „предметы быта” в брянских говорах: русскобелорусско-украинская общность. Вестник МГОУ. Серия Русская филология, № 4, с. 53-59.

Антипова, О. А. (2016). Говоры Унечского района Брянской области. Online: https://museumunecha.ucoz.net/publ/issledovanija/issledovanija/govory_unechskogo_rajona_brjanskoj_oblasti/2-1-0-7 (15.07.2018).

Бабушкин, А. Н. (1958). Брянская область: Географический и историко-экономический очерк. Брянск: Брянский рабочий.

Батожок, Н. И. (1994). Брянские говоры в восточнославянском диалектном ландшафте: Пространственные и временные параметры. Автореферат диссертации на соискание ученой степени доктора филологических наук. Институт лингвистических исследований Российской Академии Наук. Санкт-Петербург.

Брежнев, Э. Д. (ред.). (1986). Брянску - 1000 лет: Сборник документов и материалов. Тула: Приокское Книжное Издательство.

Брянску - 1000 тет: сборник документов и материалов (1986). Брянск: Приокское Книжное Издатательство.

Ведомости Верховного Совета СССР (1944), № 36. Президиум Верховного Совета Российской Советской Федеративной Социалистической Республики.

Воссоединение Украины с Россией. Документы и материаль: в 3 m. (1953). Т. 1: 1620-1647 годы. Москва: Издательство Академии Наук СССР.

Говоров, М. М., Соколов, В. К. (1955). Исторические места Брянской области. Брянск. 
Деханов, В. Г. (2013). Странищы из жизни старого Брянска. Брянск: [б. и.].

Диалектные слова и выражения села Овстуг. Online: http://libryansk.ru/zhukovskij-rajon-s-ovstug-dialekty.23008/ (12.07.2018).

Карта Брянской области. Online: http://ruhov-school.ucoz.ru/Futag/karta_brjanskoj_oblasti_1. jpg (18.07.2018).

Кожинова, А. А., Щербач И. М. (2005). Некоторые проблемы изучения заимствований из западноевропейских языков в русских диалектах (Some Problems in Study of Loan Words from Western European Languages in Russian Dialects). Russian Linguistics, vol. 29, № 3, c. 347-364. Online: https://www.jstor.org/stable/40160796?seq=5\#page_scan_tab_contents (15.07.2018).

Костомаров, Н. И. (1993). Русская история в жизнеописаниях ее главнейших деятелей. Москва: Мысль.

Крашенинников, В. В. (2001). История Брянского края, с древнейших времен до кониа ХІХ в. Ч. 1. Брянск: Издательство БГПУ.

Лингвистический энииклопедический словарь. (1990). Москва: Советская энциклопедия.

Ожегов, С. И., Шведова, Н. Ю. (1992). Толковый словарь русского языка. Москва: Азъ.

Пенюкова, И. В. (2011). Взаимосвязь языков и культур русского и украинского народов (на материале медицинской лексики говоров Западной Брянщины). Русский и иностранные языки и методика их преподавания: Вестник Российского университета дружбы народов, № 1, c. 108-113. Online: http://journals.rudn.ru/russian-language-studies/article/view/10342 (14.07.2018)

Поклонский, Д. Р. (1998). Стародубская старина. ХІ-ХІХ вв. Исторические очерки. Кн. 1, Клинцы: Издательство Клинцовской городской типографии.

Расторгуев, П. А. (1973). Словарь народных говоров Западной Брянщины (Материалы для истории словарного состава говоров). Ред. Е. М. Романович. Минск: Наука и техника.

Речь Посполитая. Online: https://ru.wikipedia.org/wiki/Речь_Посполитая (14.07.2018).

Кузнецов, П. С. (ред.). (1973). Русская диалектология: учебное пособие для педагогических институтов под ред. П. С. Кузнецзова. Москва: МГУ.

Нефедовая, Е. А. (1999). Русская диалектология: учебное пособие под редакиией Е. А. Нефедовой. Москва: МГУ.

Касаткин, Л. Л. (1989). Русская диалектология: учебник для педагогических институтов под редакцией Л. Л. Касаткина. Москва: Просвещение.

Седойкина, Ю. В. (2011). Наименования тии в брянских говорах: семантика, словообразование, ареальные связи. Автореферат диссертации на соискание ученой степени кандидата филологических наук. Брянский государственный университет имени академика И. Г. Петровского. Курск.

Седойкина, Ю. В. (2010). Заимствования из близкородственных языков в брянских говорах (на материале наименований лиц). Вестник РУДН. Серия Русский и иностранные языки и методика их преподавания, № 3, с. 116-120.

Жуков, Е. М. (1973-1982). Советская историческая энциклопедия. Москва: Советская энциклопедия.

Соколов, Я. Д. (2001). Седая Брянская старина. Брянск: Чнтаи-город.

Структура войск ВКЛ в середине XVII века. Online: http://zbroevy-falvarak.by/struktura-vojskvkl-v-seredine-xvii-veka/ (18.07.2018).

Чагишева, В. И. (1953). О брянских говорах. Ученье записки ЛГПИ им. А. И. Герцена, с. 175-212.

Тарасова, Н. Исследовательская работа на тему: „Стародубский говор”. Online: https://sibac. info/shcoolconf/hum/i/29415 (21.07.2018). 
Чагишева, В. И. (1968). Брянская область в истории и лингвистике. В: Брянские говоры. Материалы и исследования по диалектологии (к изучению брянских говоров). Ученые записки ЛГПИ им. А. И. Гериена. Т. 325, Ленинград, с. 3-9.

Чагишева, В. И. (1978). Изучение брянских говоров за 60 лет. В: Брянские говоры, Ленинград, c. 3-7.

Язык русской деревни: школьный общеобразовательный атлас: пособие для общеобразовательных учреждений. (1994). Москва.

\section{Словари брянских говоров}

Курганская, Н. И. (2007). Брянский областной словарь. Брянск: БГУ.

Расторгуев, П. А. (1973). Словарь народных говоров Западной Брянщины. Минск: Наука и техника.

Словарь брянских говоров (1976-1988). Вып. 1-5. Ленинград: ЛГПИ им. А. И. Герцена. 